\title{
Financing constraints, equity pledge and the quality of information disclosure
}

\author{
Yin Changlie ${ }^{1}$ Yuan Jing ${ }^{2}$ \\ ${ }^{1}$ Sichuan University Chengdu, China \\ ${ }^{2}$ Sichuan University Chengdu, China
}

\begin{abstract}
The application of big data in enterprise management is more and more common. With the data of A-share listed companies in Shenzhen Stock Exchange from 2014 to 2018, this paper examines the influence of controlling shareholders equity pledge on the quality of information disclosure and the moderating effect of financing constraints in the age of big data. There are two key findings. First, the controlling shareholders will take opportunistic action to reduce the quality of information disclosure so as to maintain the stock price and avoid the loss of control. And the higher the proportion of equity pledged, the stronger the incentive. Second, this phenomenon is influenced by the financing constraints, which means the negative relationship between equity pledge and the quality of information disclosure is more significant in high financing constraint enterprise than in low financing constraint enterprise. The above conclusions provide enlightenment for optimizing enterprise information disclosure in the era of big data.
\end{abstract}

\section{Introduction}

Since the newly amended "Company Law" in 2013 requires that securities companies can undertake the business of equity pledge, it has gradually developed into a very common financing method in China's capital market, which has aroused the attention of lots of scholars. Abundant research achievements have been made on the motivation and economic consequences of equity pledge. As a financing means that is accepted by major shareholders and the capital market, we should pay more attention to the negative impact of equity pledge compared with its financing advantage of transforming the static equity of major shareholders into dynamic capital [1]. Equity pledge is a kind of financing activity with high risks. The reason is that after the equity pledge, the major shareholders are faced with both the risk of the losing control and the risk of over-leverage [2]. For the sake of resolving these two potential threats, there is an inevitable opportunistic motivation to influence the financial behavior of the company by exercising its control. The existing research shows that the negative effect of the equity pledge is mainly embodied in two aspects: agency problem and market value management. On the one hand, after equity pledge, the separation of cash flow rights and control rights of controlling shareholders deepens, which leads to more serious principal-agent problems, such as occupying the company's assets, emptying the company and damaging the value of the enterprise. On the other hand, in order to avoid the risk of the transfer of control rights brought about by equity pledge, the controlling shareholders have the motivation to take opportunistic actions to manage the market value and maintain the stock price, which is manifested in the adoption of smoothing earnings, selective use of accounting policies and intervention in information disclosure. The above research shows that the negative economic consequence of equity pledge deserves more attention.

The related information disclosed by listed companies provides an important reference for investors to make decisions. The quality of information disclosure directly affects the efficiency of market investment. After equity pledge, the investors are more sensitive to the stock price. When the stock price drops, the negative signal to the market is amplified through the market mechanism, which aggravates the risk of the stock price collapse of the enterprise, and the controlling shareholders will suffer more losses. Therefore, it is a goal for controlling shareholders to take opportunistic action to maintain the stability of stock price after equity pledge. However, the market value management through earnings management not only has limited operating space, but also faces greater risks. In contrast, selective information disclosure reveal more good news and hide the bad news, is a more secure and feasible way. This paper attempts to clarify the relationship between equity pledge and the quality of information disclosure of enterprises. Taking both accounting information and non-accounting information into consideration, it reveals the negative effect of equity pledge on information disclosure of enterprises. At the same time, combined with the financing constraints faced by enterprises, this paper explores the specific existence of this negative impact in order to provide some enlightenment and reference for the formulation of 
information disclosure policy and enterprise supervision of equity pledge.

\section{Theoretical analysis and hypothesis developmentn}

\subsection{Controlling shareholders equity pledge and the quality of information disclosure}

Existing Research (Wang Bin and Song Chunxia, 2015; Chen Gongrong et al., 2016; Xie Deren and Liao Ke, 2018) shows that enterprises have positive earnings management behavior after equity pledge [3-5]. On the one hand, equity pledge closely relates the stock price to the control rights of major shareholders, and a severe fall in the stock price may result in a threat to the ownership of the assets and interests of the enterprise by the major shareholders who own the pledged equity. Therefore, after the equity pledge, the major shareholders have a strong incentive to implement positive earnings management in order to signal to outside investors that the company is performing well, enhance investor confidence, and avoid the risk of stock price collapse. On the other hand, the imperfect development of the capital market has led to the negative transfer of information from equity pledge to the market, which is not conducive to maintaining the ability of enterprises refinance. It will be a potential "mine" for enterprises when they have financing difficulties. For refinancing and the long-term and steady development of the corporation, the major shareholders have the motivation to continue the positive earnings management activities after obtaining the loan. Although there are some more subtle and unobservable ways, earnings management has less space to operate than the selective disclosure of corporate information, and is exposed to greater risks and losses once it is detected. In contrast, selective information disclosure without violating the requirements of accounting standards and rules is more safe and reliable. After equity pledge, the third party will be brought into the supervision and management system of the enterprise. The financial activities of the pledged enterprises will be more strictly supervised and the space for earnings management will be smaller. The adoption of other legal approaches to manage market value has become a consensus among shareholders. According to Company Law, Securities Law, Information Disclosure Measures of Listed Companies and Stock Listing Rules and other relevant provisions, enterprise information disclosure is divided into regular announcement and temporary disclosure. Regular announcements have strict rules about when and what to disclose, operation space is limited. In contrast, intervening temporary announcement is more feasible.

Although the object of disclosure should be important information in the development process of an enterprise, it is difficult to measure and judge quantitatively, so the enterprise has more space to judge and operate itself. After equity pledge, in order to avoid the risk of losing control, the controlling shareholders have a stronger motive to interfere with the information disclosure of enterprises by taking opportunistic action, and they are more inclined to make selective information disclosure, thus damaging the quality of information disclosure of enterprises. Li Changqing and Peric Lee (2017) found that listed companies prefer to disclose good news on a trading day after the pledge, and when the share price reduces to the unwinding line, the controlling shareholder will interfere with the information disclosure [6]. Li Laifang and Chen Zhanliao (2018) also found that the motivation and behavior of selective disclosure exist in post-pledge companies, which will damage the quality of corporate information disclosure, short-selling mechanism and institutional investors have a strong external governance effect, which is helpful to monitor the company's information disclosure behavior and improve the quality of information disclosure [7]. Based on the above analysis, the following hypotheses are proposed:

H1: The enterprise information disclosure quality has a negative association with controlling shareholders equity pledge.

H2: The equity pledge proportion has negative influence on the quality of information disclosure, which means the higher the proportion of equity pledge, the worse the quality of information disclosure.

\subsection{Financing restriction, equity pledge and the quality of information disclosureUnits}

The mechanism of the negative effect of financing constraints on the quality of information disclosure and equity pledge includes the following two aspects. On the one hand, controlling shareholders, whose part or all of the equity is pledged, will face the risks of control transfer and leverage at the same time. In order to avoid these risks, the controlling shareholder has the opportunism motive to interfere with the information disclosure of the enterprise and make the information selective disclosure. Due to financing constraints, enterprises are unable to seize good investment opportunities to increasing enterprise value, leading to the decline of stock price and aggravating the risk of losing control. From this point of view, financing constraints will strengthen the incentive to intervene in information disclosure. Chen Shen et al. (2020) found that when companies face high financing constraints, in order to achieve IPO eligibility, improve credit rating, carry out equity refinancing and obtain necessary external financing, enterprises will adopt the opportunistic behavior of earnings management [8]. On the other hand, Liu Xiaojun and Lu Wenqi (2020) found that equity pledge increases the risk of stock price collapse, and the existence of financing constraints intensifies the positive impact of equity pledge on the risk of stock price collapse [9]. Chen Yize et al. (2018) found that after equity pledge, the capital occupation of major shareholders of the enterprise increased significantly[10]. When an enterprise faces financing constraints as well as the pledge of controlling shareholders' equity, the controlling shareholders' opportunism motivation becomes more intense. They will be more urgent to intervene the information disclosure of enterprises in order to alleviate the potential adverse effects of equity pledge. Therefore, the third hypothesis of this paper is put forward: 
H3: Compared with enterprises with low financing constraints, equity pledge of controlling shareholders in enterprises with high financing constraints significantly inhibits the quality of corporate information disclosure.

\section{Research design}

\subsection{Sample and data}

The sample of this paper is A-share listed company in Shenzhen Stock Exchange from 2014 to 2018. The pledge data of controlling shareholders equity comes from WIND database, and part of the missing data is obtained from the annual report of the listed company. The information disclosure quality data are based on the listed companies' information disclosure quality evaluation data disclosed on the official website of Shenzhen Stock Exchange. In order to avoid endogenous interference, the financing constraint is measured by the SA index constructed by Hadlock \& Pieree(2009). The calculate--ion formula of the SA index is: $-0.737 *$ Size $+0.043 *$ Size $^{2}-0.04 *$ Age [11]. Other relevant data come from the CSMAR Database. Considering the financial particularity of ST Company and financial enterprises, this kind of data will be excluded in the study. After eliminating the missing variable data, we end up at a final sample of 7248 observations for the period 2014-2018 that satisfy all our data requirements. Considering the influence of data extreme value on the research conclusion, all continuous variables are treated with $1 \%$ tail reduction.

\subsection{Measurament of variables}

The explained variable of this paper is the quality of information disclosure. It comes from the evaluation results of information disclosure quality of A-share listed companies disclosed on the official website of Shenzhen Stock Exchange. The results are divided into four levels: excellent, good, qualified and unqualified, which are respectively represented by the letters $\mathrm{A}, \mathrm{B}, \mathrm{C}$ and $\mathrm{D}$. On this basis, sets the sequence variable Disclosure as the agent variable of the quality of information disclosure. The value of the sequence variable was 4,3,2 and 1, which respectively represented the evaluation result was excellent, good, qualified and unqualified (A, B, C and D). There are two types: component heads and text heads.

Referring to the related literature, the explanatory variable is measured by the following two variables: one is the dummy variable of the pledge of controlling shareholders equity (Pledge). At the end of the year, if the listed company has controlling shareholders equity pledge, the value is 1; otherwise, the value is 0 ; The other is Pledgeratio, which is defined as the proportion of pledged shares in the listed company at the end of the year.

To examine the role of financing constraints in the negative relationship between controlling shareholders equity pledge and the quality of information disclosure, this paper uses SA Index to measure the financing constraints faced by enterprises. Considering that SA index is negative, and the greater the absolute value, the higher the degree of financing constraint. This paper takes the mean value of SA index as the boundary. If the SA value is less than the mean value, the HSA variable is 1 ; otherwise, it is 0 . Therefore, the group is divided into the high financing constraint group and the low financing constraint group.

According to the prior studies, the control variables are enterprise scale(Lnsize), financial leverage(Lev), return on net assets(Roe), ownership concentration(Top1), independent dire--ctor proportion(Independent), executive compensation (Lnpay), board size(Lnboard) and audit quality (Big4). All of the control variables are detailed in Table1.

\subsection{Regression model}

Considering that the explained variable in this study is a discrete variable,the following regression model is constructed:

First, in order to test the effect of the controlling shareholders equity pledge on disclosure quality of listed companies ( $\mathrm{H} 1$ and $\mathrm{H} 2)$, we construct the following model: Disclosure $_{i, t}=\beta_{1}$ Pled $_{i, t}+\sum \beta *$ Controls $_{i, t}+\varepsilon \quad$ (1)

Second, in order to test the moderating effect of financing constraints on the quality of information disclosure and the pledge of controlling share rights of listed companies(H3), on the basis of (1), with the mean value of the financing constraint SA index (SA) as the standard, the samples were divided into two sub-samples of the high financing constraint group and the low financing constraint group, and then the regression was carried out respectively.

Table1. CONTROL VariableS Definitions

\begin{tabular}{|c|c|l|}
\hline Variable & \multicolumn{1}{|c|}{ Measure } & \multicolumn{1}{c|}{ Description } \\
\hline LnSize & Scale of enterprise & $\begin{array}{l}\text { Natural Logarithm of total } \\
\text { assets at the end of the year }\end{array}$ \\
\hline Roe & Financial Leverage & Total liabilities / total assets \\
\hline Top1 & $\begin{array}{c}\text { Ownership } \\
\text { concentration }\end{array}$ & $\begin{array}{l}\text { Net profit after tax / year-end } \\
\text { stockholders' equity }\end{array}$ \\
\hline Independent & $\begin{array}{l}\text { Percentage of } \\
\text { by the largest shareholder in the } \\
\text { total shares of the enterprise }\end{array}$ \\
\hline LnPay & $\begin{array}{l}\text { Number of independent } \\
\text { directors / total directors on the } \\
\text { board of directors }\end{array}$ \\
\hline LnBoard & Bompensation & $\begin{array}{l}\text { The top three executive pay } \\
\text { packages are in natural } \\
\text { logarithms }\end{array}$ \\
\hline Big4 & Audit Quality & $\begin{array}{l}\text { The Natural Logarithm of the } \\
\text { number of board members }\end{array}$ \\
\hline
\end{tabular}

\section{Empirical Analysis and robustness test}

\subsection{Descriptive statistics}

Table 2 presents the descriptive analysis results of the whole sample. It can be seen from table 2 that the mean and median of the sequence variable Disclosure (values of 4,3,2 and 1) are 3.117 and 3 respectively, indicating that A-share listed companies in Shenzhen Stock Exchange have high quality of information disclosure and China's information disclosure supervision has a good effect. The 
mean value of Pledge and Pledgeratio are 0.560 and 0.303 respectively, indicating that the phenomenon of controlling shareholders equity pledge in A-share listed companies in Shenzhen Stock Exchange is relatively common.

Table2. Descriptive Statistics

\begin{tabular}{|c|c|c|c|c|c|}
\hline Variables & $\mathbf{N}$ & Mean & Min & Median & Max \\
\hline Disclosure & 7248 & 3.117 & 1 & 3 & 4 \\
\hline Pledge & 7248 & 0.560 & 0 & 1 & 1 \\
\hline Pledgeratio & 7248 & 0.303 & 0 & 0.138 & 1 \\
\hline SA & 7248 & -3.430 & -4.089 & -3.377 & -2.938 \\
\hline Lev & 7248 & 1.299 & 0.396 & 1.061 & 6.455 \\
\hline LnSize & 7248 & 21.97 & 19.97 & 21.85 & 25.47 \\
\hline Roe & 7248 & 0.0920 & 0.00300 & 0.0790 & 0.351 \\
\hline Top1 & 7248 & 0.328 & 0.0950 & 0.308 & 0.694 \\
\hline Independent & 7248 & 0.377 & 0.333 & 0.333 & 0.571 \\
\hline LnPay & 7248 & 15.30 & 13.82 & 15.25 & 17.13 \\
\hline LnBoard & 7248 & 2.104 & 1.609 & 2.197 & 2.565 \\
\hline Big4 & 7248 & 0.0290 & 0 & 0 & 1 \\
\hline
\end{tabular}

\subsection{Regression Analysis: Equity Pledge and quality of information disclosure}

To test $\mathrm{H} 1$ and $\mathrm{H} 2$, this paper adopts the panel orderedlogit model regression, and table 3 reports the regression results. Columns (1) and (2) of Table 3 respectively show the regression results when Pledge and Pledgeratio are used as the key explanatory variables without controlling other control variables except the industry and annual fixed effects. The coefficients of Pledge and Pledgeratio are -0.1984 and- 1.0395 , respectively, and are significantly negative at the level of $5 \%$ and $1 \%$ respectively. Column (3) and column (4) of Table 3 report the regression results after adding other control variables to column (1) and column (2) respectively. The results show that the coefficient of Pledge is- 0.1530 , which is significantly negative at the level of $10 \%$, and that of Pledgeratio is0.9078 , which is significantly negative at the level of $1 \%$. The above results confirm $\mathrm{H} 1$ and $\mathrm{H} 2$, which indicates that the equity pledge of the state-controlled shareholder has decreased the quality of information disclosure, and the quality of information disclosure decreases as the proportion of the pledge of controlling shareholders' equity increases. Although intervention in corporate information disclosure may touch the red line of capital market regulation, controlling shareholders who pledge equity are still willing to adopt this way to manage market value and maintain stock price stability so as to avoid the risk of control transfer.

\subsection{Regression Analysis: The impact of financing constraints}

Table 4 reports the results of the grouping regression of financing constraints. In columns (1) and (2) of Table 4, the explanatory variable is Pledge. The group with high financing constraints had a Pledge coefficient of -0.3825 , which was significantly negative at the $1 \%$ level, while the group with low financing constraints had a Pledge coefficient of -0.1011 , which was not significant. The Pvalue for coefficient difference test was 0.04 , significant at the $5 \%$ level, indicating that there was a significant difference between the two groups, thus verifies H3. Columns (3) and (4) of Table 4 take Pledgeratio as the explanatory variable, and the coefficients of the two groups are -1.1198 and -0.911 respectively, both are significantly negative at the $1 \%$ level. Although the absolute value of Pledgeratio coefficient in the high financing constraint group is greater than that in the low financing constraint group, it cannot be concluded that the negative relationship between the equity pledgeratio in the high financing constraint group and the quality of enterprise information disclosure is more significant than that in the low financing constraint group due to the overlap of their confidence intervals. Similarly, coefficient difference test is required, and the results show that there is no significant difference between the two groups. The above results indicate that compared with the proportion of equity pledge, financing constraints have a more obvious negative effect on the relationship between equity pledge and the quality of corporate information disclosure. when there are both stock pledge of controlling shareholders and high financing constraints, the quality of corporate information disclosure is worse.

Table3. Regression results for $\mathrm{H} 1$ and $\mathrm{H} 2$

\begin{tabular}{|c|c|c|c|c|}
\hline & \multicolumn{4}{|c|}{ Disclosure } \\
\hline & (1) & (2) & (3) & (4) \\
\hline Pledge & $\begin{array}{c}-0.198 * * \\
(0.085)\end{array}$ & & $\begin{array}{c}-0.153^{*} \\
(0.083) \\
\end{array}$ & \\
\hline Pledgeratio & & $\begin{array}{c}- \\
1.040^{* * * *} \\
(0.1247)\end{array}$ & & $\begin{array}{c}-0.908 * * * \\
(0.122)\end{array}$ \\
\hline Lev & & & $\begin{array}{c}-0.405 * * * \\
(0.048)\end{array}$ & $\begin{array}{c}-0.398 * * * \\
(0.048)\end{array}$ \\
\hline LnSize & & & $\begin{array}{c}0.304 * * * \\
(0.055)\end{array}$ & $\begin{array}{c}0.345^{* * *} * \\
(0.055)\end{array}$ \\
\hline Roe & & & $\begin{array}{c}4.761 * * * \\
(0.627)\end{array}$ & $\begin{array}{c}4.527 * * * \\
(0.622)\end{array}$ \\
\hline Top1 & & & $\begin{array}{c}2.330 * * * \\
(0.372)\end{array}$ & $\begin{array}{c}2.117 * * * \\
(0.367)\end{array}$ \\
\hline Independent & & & $\begin{array}{c}0.221 \\
(1.026)\end{array}$ & $\begin{array}{c}0.125 \\
(1.015)\end{array}$ \\
\hline LnPay & & & $\begin{array}{c}0.626 * * * \\
(0.086)\end{array}$ & $\begin{array}{c}0.580^{* * * *} \\
(0.085)\end{array}$ \\
\hline LnBoard & & & $\begin{array}{c}0.504 \\
(0.313)\end{array}$ & $\begin{array}{c}0.410 \\
(0.309)\end{array}$ \\
\hline Big4 & & & $\begin{array}{l}-0.179 \\
(0.29)\end{array}$ & $\begin{array}{l}-0.246 \\
(0.292)\end{array}$ \\
\hline $\begin{array}{c}\text { cut1 } \\
\text { cons }\end{array}$ & $\begin{array}{c}- \\
5.474 * * * \\
(0.494)\end{array}$ & $\begin{array}{c}- \\
5.755^{* * *} * \\
(0.485)\end{array}$ & $\begin{array}{c}12.200 * * * \\
(1.565)\end{array}$ & $\begin{array}{c}11.835 * * * \\
(1.541)\end{array}$ \\
\hline $\begin{array}{c}\text { cut2 } \\
\text { _cons }\end{array}$ & $\begin{array}{c}- \\
2.495 * * * \\
(0.478)\end{array}$ & $\begin{array}{c}- \\
2.779 * * * \\
(0.467)\end{array}$ & $\begin{array}{c}15.202 * * * \\
(1.565)\end{array}$ & $\begin{array}{c}14.834 * * * \\
(1.541)\end{array}$ \\
\hline $\begin{array}{l}\text { cut3 } \\
\text { cons }\end{array}$ & $\begin{array}{c}3.158 * * * \\
(0.480)\end{array}$ & $\begin{array}{c}2.861 * * * \\
(0.468)\end{array}$ & $\begin{array}{c}20.886^{* * *} \\
(1.583)\end{array}$ & $\begin{array}{c}20.511 * * * \\
(1.560)\end{array}$ \\
\hline $\begin{array}{c}\text { sigma2_u } \\
\text { cons }\end{array}$ & $\begin{array}{c}4.235 * * * \\
(0.264) \\
\end{array}$ & $\begin{array}{c}3.950 * * * \\
(0.251)\end{array}$ & $\begin{array}{c}3.256 * * * \\
(0.218)\end{array}$ & $\begin{array}{c}3.070 * * * \\
(0.210)\end{array}$ \\
\hline $\begin{array}{c}\text { Year\& } \\
\text { Industry }\end{array}$ & Yes & Yes & Yes & Yes \\
\hline $\mathrm{N}$ & 7255 & 7255 & 7248 & 7248 \\
\hline Wald chi2 & 53.60 & 117.72 & 454.25 & 509.33 \\
\hline
\end{tabular}


Table4. Regression results for $\mathrm{H} 3$

\begin{tabular}{|c|c|c|c|c|}
\hline & \multicolumn{4}{|c|}{ Disclosure } \\
\hline & \multicolumn{2}{|c|}{ Pledge } & \multicolumn{2}{|c|}{ Pledgeratio } \\
\hline & $\begin{array}{c}\text { (1) } \\
\text { High SA } \\
\end{array}$ & $\begin{array}{c}\text { (2) } \\
\text { Low SA }\end{array}$ & $\begin{array}{c}\text { (3) } \\
\text { High SA } \\
\end{array}$ & $\begin{array}{c}\text { (4) } \\
\text { Low SA }\end{array}$ \\
\hline Pledge & $\begin{array}{c}-0.383 * * * \\
(0.144)\end{array}$ & $\begin{array}{l}-0.101 \\
(0.101)\end{array}$ & & \\
\hline $\begin{array}{c}\text { Pledgerati } \\
\text { o }\end{array}$ & & & $\begin{array}{c}-1.120^{* * * *} \\
(0.194)\end{array}$ & $\begin{array}{c}-0.912 * * * \\
(0.155)\end{array}$ \\
\hline Lev & $\begin{array}{c}-0.449 * * * \\
(0.073)\end{array}$ & $\begin{array}{c}-0.445^{* * * *} \\
(0.064)\end{array}$ & $\begin{array}{c}-0.443 * * * \\
(0.073)\end{array}$ & $\begin{array}{c}-0.430^{* * * *} \\
(0.064)\end{array}$ \\
\hline LnSize & $\begin{array}{c}0.351 * * * \\
(0.098)\end{array}$ & $\begin{array}{c}0.345 * * * \\
(0.071)\end{array}$ & $\begin{array}{c}0.351 * * * \\
(0.096)\end{array}$ & $\begin{array}{c}0.420 * * * \\
(0.071)\end{array}$ \\
\hline Roe & $\begin{array}{c}3.030 * * * \\
(0.957)\end{array}$ & $\begin{array}{c}6.567 * * * \\
(0.830)\end{array}$ & $\begin{array}{c}3.007 * * * \\
(0.949)\end{array}$ & $\begin{array}{c}6.164 * * * \\
(0.824)\end{array}$ \\
\hline Top1 & $\begin{array}{c}2.513 * * * \\
(0.594) \\
\end{array}$ & $\begin{array}{c}2.124 * * * \\
(0.450)\end{array}$ & $\begin{array}{c}2.328^{* * * *} \\
(0.586)\end{array}$ & $\begin{array}{c}1.925^{* * *} * \\
(0.444)\end{array}$ \\
\hline $\begin{array}{c}\text { Independe } \\
\text { nt }\end{array}$ & $\begin{array}{c}0.635 \\
(1.625)\end{array}$ & $\begin{array}{c}0.418 \\
(1.288)\end{array}$ & $\begin{array}{c}0.532 \\
(1.606)\end{array}$ & $\begin{array}{c}0.300 \\
(1.274)\end{array}$ \\
\hline LnPay & $\begin{array}{c}0.737 * * * \\
(0.130)\end{array}$ & $\begin{array}{c}0.566^{* * * *} \\
(0.111)\end{array}$ & $\begin{array}{c}0.707 * * * \\
(0.128)\end{array}$ & $\begin{array}{c}0.498^{* * * *} \\
(0.110)\end{array}$ \\
\hline LnBoard & $\begin{array}{c}0.716 \\
(0.495)\end{array}$ & $\begin{array}{c}0.503 \\
(0.392)\end{array}$ & $\begin{array}{c}0.626 \\
(0.488)\end{array}$ & $\begin{array}{c}0.388 \\
(0.387)\end{array}$ \\
\hline Big4 & $\begin{array}{c}-0.326 \\
(0.403)\end{array}$ & $\begin{array}{c}-0.208 \\
(0.443)\end{array}$ & $\begin{array}{c}-0.352 \\
(0.397)\end{array}$ & $\begin{array}{c}-0.313 \\
(0.439)\end{array}$ \\
\hline $\begin{array}{l}\text { Year\& } \\
\text { Industry }\end{array}$ & Yes & Yes & Yes & Yes \\
\hline $\mathrm{N}$ & 2872 & 4376 & 2872 & 4376 \\
\hline Wald chi2 & 219.63 & 309.43 & 245.78 & 343.37 \\
\hline$p$-value & & & & \\
\hline
\end{tabular}

\subsection{Robustness tests}

Considering that the systematic differences between listed companies with and without equity pledge may interfere with regression results, this paper adopts the propensity score matching (PSM) method to alleviate this problem and enhance the robustness of test results. The company size, financial leverage, return on equity, equity concentration, proportion of independent directors, executive compensation, scale of the board of directors and audit quality were used to one-to-one match whether there was any pledge of controlling shareholders' equity. Finally, 5,997 control samples were obtained. The result of ordered-logit regression showed that the coefficient of the explanatory variable Pledge was -0.2170 , significantly negative at $5 \%$ level, which confirms $\mathrm{H} 1$.

Table5. Regression results of PSM robustness test

\begin{tabular}{|c|c|}
\hline & Disclosure \\
\hline Pledge & $\begin{array}{c}-0.2170 * * \\
(0.0907) \\
\end{array}$ \\
\hline Lev & $\begin{array}{c}-0.3795^{* * *} \\
(0.0512)\end{array}$ \\
\hline LnSize & $\begin{array}{c}0.1426^{* * *} \\
(0.0548)\end{array}$ \\
\hline Roe & $\begin{array}{c}5.9545 * * * \\
(0.6820)\end{array}$ \\
\hline Top1 & $\begin{array}{c}2.4946 * * * \\
(0.3894)\end{array}$ \\
\hline Independent & $\begin{array}{c}0.1273 \\
(1.1011) \\
\end{array}$ \\
\hline LnPay & $\begin{array}{c}0.5217 * * * \\
(0.0892)\end{array}$ \\
\hline LnBoard & $\begin{array}{l}0.6495^{*} \\
(0.3346)\end{array}$ \\
\hline Big4 & $\begin{array}{l}-0.3164 \\
(0.3585)\end{array}$ \\
\hline $\mathrm{N}$ & 5997 \\
\hline Wald chi2 & 334.61 \\
\hline
\end{tabular}

\section{CONCLUSIONS}

Equity pledge has become an increasingly popular financing method for A-share market due to its advantages of simplicity and convenience, not decentralize control. However, relevant theories and practices both show that equity pledge has brought some negative effects that cannot be ignored. This paper selects relevant data of Ashare listed companies in Shenzhen Stock Exchange from 2014 to 2018 as research samples, conducts regression analysis using panel ordered-logit model, and tests the relationship between equity pledge of controlling shareholders and the quality of corporate information disclosure. The results show that the pledge of controlling shareholders' equity has a negative impact on the information disclosure quality of enterprises, and indicates that the pledge of controlling shareholders' equity enhances the motivation of enterprises to make selective information disclosure and reduces the quality of information disclosure. On this basis, the regulating effect of financing constraints is further verified, and it is found that compared with enterprises with low financing constraints, the negative relationship between equity pledge and enterprise information disclosure quality is more significant in enterprises with high financing constraints.

\section{References}

1. Zhang Shuanxing, Wen Yanze, Yang Xinyi. "Equity pledge, equity structure and earnings management," J. Friends of Accounting, vol. 14, pp. 130-136, 2019.

2. Ai Dali, Wang Bin, “On major shareholders' equity pledge and finance of listed companies: influence mechanism and market reaction," J. Journal of Beijing Technology and Business University(Social Sciences), vol. 27(04): pp. 72-76, 2012.

3. Wang Bin,Song Chunxia, "Major shareholders' equity pledge, the nature of equity and the way of earnings managemen," J. East China Economic Management, vol. 29(08), pp. 118-128, 2015.

4. Chen Gongrong, Li Jingyi, Cai Shuren, "Research on the influence of equity pledge of major shareholders on earnings management," J. Friends of Accounting, vol. 14, pp. 12-17, 2016.

5. Xie Deren, Liao Ke, Zheng Dengjin. "Controlling shareholders equity pledge and the implicit choice of accounting policy of development expenditure," J. Accounting Research, vol. 3, pp. 30-38+94, 2017.

6. Li Changqing, Peric Lee, "Equity pledge of controlling shareholders and information disclosure of listed companies," J. Statistical Research, , vol. 34(12), pp. 75-86, 2017.

7. Li Laifang, Chen Zhanliao, "Does pledge of controlling shareholders' equity reduce the quality of information disclosure?" J. Scientific Decision Making, vol. 8, pp. 1-20, 2018.

8. Chen Shen, Deng Chunmei, Chen Hanwen, "Financing constraints, internal control and earnings 
management strategies," J. Southeast Academic Research, vol. 4, pp. 147-156, 2020.

9. Liu Xiaojun, Lu Wenqi. "Financing constraints, equity pledge and stock price crash risk," J. CoOperative Economy \& Science, vol. 10, pp. 64-67, 2020.

10. Chen Zeyi, Li Changqing, Huang Zhonghuang. "Equity pledge, equity incentive and capital occupation of major shareholders," J. South China Finance, vol. 3, pp. 23-32, 2018.

11. Charles J. Hadlock, Joshua R. Pierce. "New evidence on measuring financial constraints: moving beyond the KZ index,” J., vol. 23(5), pp. 1909-1940, 2010. 